\title{
Socio-Economic Impact Of Tourism In Sauraha Chitwan, Nepal
}

\author{
Teaching Assistant, Department of Geography \\ Education, T. U., Nepal
}

\begin{abstract}
In Nepal, the number of tourist arrivals and stay their length have been increasing day to day. This incensement has directly influenced the socio-economic status of Nepalese people. The main objective of this paper is to explore the socioeconomic impact of tourism on Sauraha. To fulfill the objective both primary and secondary data had been used. There are both direct and indirect impacts on socio-economic condition of local people. Tourism has contributed a lot a raising the awareness among the communities, preserving traditional culture, values, norms and heritage. But it is also facing a problem of sanitation, improper solid waste management, unmanaged dumping site and poaching wild life. Tourism development in Sauraha should be assessed both the local traditions and culture.
\end{abstract}

Key Words: Tourism, socio-economic impact, World Heritage Site, sustainable development

\section{INTRODUCTION}

In general term, 'tourism' denotes the journey of human beings from one place to the another, where it may be within own country or second countries for various purposes. The word 'Tourism' which was originated in the $19^{\text {th }}$ century and was popularized in 1930s, but its significance was not fully realized until today when 'tourism' has a wider meaning and significance (Satyal 1988).Various scholars have defined the words tourism, tour and tourist in different ways and yet there is no universally accepted definition. A famous Austrian Political Economist Herman Von Schullard defines "Tourism is the sum total of operators mainly of an economic nature which directly relates to the entry, stay and movement of foreigners inside and outside certain country, city or region" (cited in Williams, 2004:49). Another definition of tourism was given by Edmond Picard. According to him, "the functions of tourism are to import currency from foreign resources into country. Its impact is what tourist expenditures can do to the different sectors of the economy and in particular the hotel keepers" (Chauhan, 2003).

At present, tourism is growing faster in developing countries both for arrivals and receipts, reflecting a wider redistribution of tourism revenues in favor of and new emerging tourism destination for the third world. Thus tourism is going to be most important industry in the world today. Tourism is the world's largest export industry. Tourism provides both direct and secondary employment. Direct employment includes accommodation, restaurants, bars, shops, night clubs, transport operators and government administration of tourism. And secondary employment embraces the construction, agriculture and fishing, manufacturing and processing sectors. Tourism has direct or indirect social and economic benefits. Economic benefits are, increased government revenue through various types of taxation, create a jobs and increase family and community income, provide the opportunity for innovation and creativity, provides the support for existing business and services, helps to develop local crafts and trade and develop international peace and understanding. Similarly, social benefits are, helps to build up a community infrastructure, provides the opportunities for cultural exchange, develop international peace, friendship and understanding, promotes a team community spirits particularly through the development of cultural and entertainment activities, create conditions for safe guarding and enhancing local cultural identities. Tourists not only bring money to region; they also carry along with them a strong and visible life style. Their dress, food habits and merry-making style all bring some newness and uniqueness to the area of their visit (Gupta 2002). Thus tourism has direct or indirect socio-economic impacts on that area where they visited.

Tourism has been one of the major economic activities in many countries, like Nepal. Tourism industry plays a vital role for the development of the national economy. Development of tourism sector can influence in various sectors such as increasing employment generating foreign exchange extending tourist related business as well as to improve the balance of payment of the country. Tourism is one of the main sources of foreign exchange earnings. Tourists not only bring money to Nepal; they also carry along with them a strong and visible life style which is directly influence of Nepalese lifestyle and economy. Variety of jobs in resorts and lodges including tourist guide, cooking, making dresses, preparation of food are the major ones. They brought different merry-making style also, newness 
and uniqueness of that area where tourists visit. Thus, social and economic status of Nepalese people has been perceived changes and direct impact on them. In such case, this study try to find out what kind of social and economic impact has been created by tourism in Sauraha area in Chitwan district of Nepal

\section{STUDY AREA}

The geographical location of Chitwan district is $83^{\circ} 55^{\prime} 45^{\prime \prime}$ east to $84^{\circ} 48^{\prime} 15^{\prime \prime}$ east longitude and $27^{0} 52^{\prime} 36^{\prime \prime}$ north to $27^{\circ} 46^{\prime}$ north latitude. Temperature reaches a maximum $40^{\circ} \mathrm{C}$ (in May) and minimum of $6^{\circ} \mathrm{C}$ (in December). It lies between the Mahabharat and Churiya hills. Chitwan has tropical and subtropical monsoon climate with high humidity and four main seasons: summer, monsoon, autumn and winter. It is endowed with the rich basins and valleys. The valley consists of outer most series of low-elevation hills and mountains of the Himalayas and the Mosaic of riverine forest, grass lands and sub-tropical sal (Shorea robusta) forest supporting a wide diversity and native flora and fauna including endangered animals and wildlife species. Chitwan valley is uniquely endowed with rich natural, cultural and religious heritage. Chitwan covers 2,519 square kilometer or 1.51 percent of total area of Nepal. There are so many important tourists sports such as Devghat, Balmiki Ashram, Chitwan National Park, Bikram Baba, Upardang, godhi, Someshwar Chitrasari, Goddak Bageswari, Shivaghat, Kabilas, Gadhi, Purana godhi, Ichhaya Kamana, Kalikasthan, Bees Hazartal, Tribeni, Parshuram Kunda, Shirapanchayan Temple etc. Sauraha is one of them and the most famous destination for tourist.

Sauraha lies in Bacchhauli VDC. Which is 166 kilometers south west form Kathmandu. It is situated at an altitude of $150 \mathrm{~m}$ form the sea level. Tandi is the entry point of Sauraha, whereas Sauraha is the only a major location for tourist to see the wildlife of Chitwan National Park. Chitwan National Park covers 932 square kilometer area which is established in 1973 and UNESCO has enlisted this area on the "World Heritage Site" in 1984. The park is consisted by various flora and fauna.

\section{METHODS AND MATERIALS}

The main objective of this paper is decribed the socio-economic impact of tourism development in Sauraha. To fulfill the objective both primary and secondary data have been used. Primary data were collected through interview of tourists, local people, and proprietors of hotels/restaurants. Information related with physical infrastructures, different activities by hotel, restaurant and local agencies was collected through field observation. Secondary data were obtained from various published and unpublished sources such as relevant literature, news papers and journals of tourism, research report and annual report of Nepal Tourism Board (NTB) and Chitwan National Park (CNP).

\section{TOURIST ARRIVALS}

Among the different national parks and wildlife conservations of Nepal Chitwan National Park occupies the large share of tourists visiting. Tourism in Chitwan has been started since the early 1970, especially after the establishment of CNP (Chitwan National Park) in 1973, the volume of tourists visiting Chitwan ever growing. In Sauraha endangered wild animals such as one horn rhinoceros, tiger, gharial, crocodile etc. are found. Tharu culture in Sauraha is the main reason for the large share of tourist arrivals over there. The number of tourist visiting in Sauraha has been given in the Table 1 .

Table 1: The Number of Tourist Visiting (1999 2008).

\begin{tabular}{|c|c|c|c|}
\hline Year & $\begin{array}{c}\text { Total Tourists } \\
\text { arrivals in } \\
\text { Nepal }\end{array}$ & $\begin{array}{c}\text { Arrivals in } \\
\text { Sauraha }\end{array}$ & $\begin{array}{c}\text { Percentage } \\
\text { in Sauraha }\end{array}$ \\
\hline 1999 & $4,91,504$ & $1,05,084$ & 21.38 \\
\hline 2000 & $4,63,646$ & $1,17,512$ & 25.34 \\
\hline 2001 & $3,61,237$ & $1,06,242$ & 29.44 \\
\hline 2002 & $2,75,468$ & 58,317 & 21.17 \\
\hline 2003 & $3,38,132$ & 48,921 & 14.46 \\
\hline 2004 & $3,85,297$ & 57,846 & 15.1 \\
\hline 2005 & $3,75,679$ & 42,644 & 13.1 \\
\hline 2006 & $3,93,613$ & 83,859 & 21.30 \\
\hline 2007 & $4,21,857$ & 96,062 & 22.77 \\
\hline 2008 & $4,63,684$ & $1,04,646$ & 22.44 \\
\hline
\end{tabular}

Source: CNP Record 2009.

The share of tourist visiting Sauraha was in increasing trend between 1999 and 2008 (2056 to 2065 B.S.) except in 2002 to 2005. The arrival of tourist in Sauraha was almost similar with the national trend. The main reason seems the increasing polytypical instability and insecurity in the country during those years. But after 2005, peace is maintained in the country and political situation is also being developed. Therefore, the number of tourist's arrivals in Nepal has been increased and the Sauraha also has the same trend.

\section{PURPOSE OF TOURIST ARRIVALS}

Most of the tourists visiting Nepal have the objectives of entertainment, trekking and mountaineering. The 
tourists visiting the Sauraha may have the purpose of seeing National park peace full environment and recreation etc. The purpose of visit in Sauraha is given in Table 2.

Table 2: Purpose of Tourist Arrivals

\begin{tabular}{|l|c|c|}
\hline \multicolumn{1}{|c|}{ Purpose } & $\begin{array}{c}\text { No. of } \\
\text { Respondent }\end{array}$ & Percentage \\
\hline National park & 16 & 32 \\
\hline Wild life & 8 & 16 \\
\hline Peaceful environment & 4 & 8 \\
\hline Recreation & 6 & 12 \\
\hline Slight seeing & 4 & 8 \\
\hline $\begin{array}{l}\text { Boating and elephant } \\
\text { riding }\end{array}$ & 10 & 20 \\
\hline Other/study, research & 2 & 4 \\
\hline Total & 50 & 100 \\
\hline Source: FieldSurvey, 2009
\end{tabular}

Source: Field Survey, 2009

The highest number of visitors came to Sauraha with the purpose of visiting the National Park and boating and elephant riding. Out of 50 respondents interviewed, 32 percent reported national park visiting, 20 percent boating and elephant riding, 16 percent wildlife and remaining other said that major purpose of visiting Sauraha is peaceful environment, recreation, sightseeing and other purposes such as study and research.

\section{LENGTH OF STAY}

The length of stay is crucial factor in tourism development. In order to develop tourism industry, it is necessary not only to increase the number of tourists inflow but also to increase their length of stay. The length of stay depends on time, money and desire of tourist. The length stay by tourists visit in Sauraha is given in Table 3

Table 3: Length of Stay

\begin{tabular}{|l|c|c|}
\hline \multicolumn{1}{|c|}{ Stay period } & $\begin{array}{c}\text { No. of } \\
\text { Respondents }\end{array}$ & Percentage \\
\hline One to two days & 17 & 34 \\
\hline Three to four days & 29 & 58 \\
\hline Five days to one week & 4 & 8 \\
\hline More than one week & - & - \\
\hline Total & 50 & 100 \\
\hline
\end{tabular}

Source: Field Survey 2009
The majority of tourists (58\%) visited Sauraha for three to four days, $34 \%$ tourist visited for one to two days and five days to one week stay are very few (only $8 \%$ ), whereas no tourists are found more than week staying in Sauraha.

\section{EXPENDITURE PATTERN}

The tourist's expenditure pattern depends upon available facilities and their purposes. It is also related to the length of stay. Table 4 shows the expenditure patterns of the tourist between December to Janabary 2006.

\section{Table 4 : Expenditure Pattern}

\begin{tabular}{|l|c|c|}
\hline $\begin{array}{l}\text { Amount of daily } \\
\text { expenditure by one } \\
\text { tourist (in \$) }\end{array}$ & $\begin{array}{l}\text { No. of } \\
\text { Respondents }\end{array}$ & Percentage \\
\hline Up to 20 US \$ & 18 & 36 \\
\hline 21 to 40 US \$ & 14 & 28 \\
\hline 41 to 50 US \$ & 9 & 18 \\
\hline More than 50 US \$ & 9 & 18 \\
\hline Total & 50 & 100 \\
\hline
\end{tabular}

Source: Field Survey, 2009

Survey of 50 tourists, 36 percent spends up to 20 dollars per day, 28 percent spends 20 to 40 dollars and 18 percent spends 41 to 50 dollars per day. Similarly, 18 percent spends more than 50 dollars per day.

\section{ACCOMMODATION CAPACITY}

The history of tourism in Chitwan is relatively short. The first tourist lodge was built in early 1960s. Presently, there are several hotels and lodges. Now there are altogether 20 hotels, lodges or resorts operating in and around Sauraha. Among them some hotels also found to be owned by the local Tharu. Most of the hotels are built on the bank of the Rapti River and scattered around within the circumference of about $2 \mathrm{~km}$ from the gate of CNP. The distance between one hotel to another is not more than $50 \mathrm{~m}$. Some are close to each other. Among these hotels, some are restaurant operating and bars. The available facilities and services differ from one hotel to another. The accommodation capacity of hotels is also a responsible factor for earning foreign currency. Accommodation capacity of hotels varies across different class of hotels in Sauraha. The price variation of accommodation is also a crucial factor for the growth of lodges as well as tourism industry (Table 5). 
Table 5 : Hotels and Lodge

\begin{tabular}{|c|c|c|c|c|}
\hline \multirow[t]{2}{*}{ S.N } & \multirow[t]{2}{*}{ Name of Hotel } & \multicolumn{2}{|c|}{ Capacity } & \multirow[t]{2}{*}{ Staff } \\
\hline & & Rooms & Beds & \\
\hline 1 & Rhino Lodge & 28 & 56 & 22 \\
\hline 2 & Royal Park Hotel & 25 & 50 & 20 \\
\hline 3 & The Rhino Residency & 24 & 48 & 15 \\
\hline 4 & $\begin{array}{l}\text { Traveller's Jungle } \\
\text { Camp }\end{array}$ & 24 & 48 & 10 \\
\hline 5 & Hotel Heritage & 23 & 46 & 52 \\
\hline 6 & Jungle M. Resort & 20 & 40 & 15 \\
\hline 7 & Jungle Safari Park & 18 & 36 & 10 \\
\hline 8 & Jungle Safari Lodge & 17 & 34 & 19 \\
\hline 9 & CTC & 17 & 34 & 25 \\
\hline 10 & Holiday safari lodge & 17 & 34 & 10 \\
\hline 11 & $\begin{array}{l}\text { Hotel Himalayan } \\
\text { Safari }\end{array}$ & 16 & 32 & 15 \\
\hline 12 & $\begin{array}{l}\text { Jungle Adventure } \\
\text { World }\end{array}$ & 16 & 32 & 21 \\
\hline 13 & $\begin{array}{l}\text { Chitwan Paradise } \\
\text { Hotel }\end{array}$ & 15 & 30 & 21 \\
\hline 14 & Jungle World Nepal & 15 & 30 & 12 \\
\hline 15 & Chitwan Rest Camp & 12 & 24 & 21 \\
\hline 16 & Garden Guest House & 12 & 24 & 12 \\
\hline 17 & $\begin{array}{l}\text { Chitwan Resort } \\
\text { camp }\end{array}$ & 11 & 22 & 15 \\
\hline 18 & River side & 10 & 20 & 10 \\
\hline 19 & $\begin{array}{l}\text { Chitwan park } \\
\text { cottage }\end{array}$ & 10 & 20 & 19 \\
\hline 20 & Jungle Rest Lodge & 7 & 14 & 18 \\
\hline & Total & & & 362 \\
\hline
\end{tabular}

Source: Field Survey, 2009.

The number of rooms and beds of the hotels, lodges and resorts are not equal. All total 362 persons are employing in hotels, lodges and resorts.

\section{MARKET SOURCE OF GOODS FOR HOTELS.}

Tourism has played a vital role in the expansion of market in Sauraha. The hotel and lodges purchase good from Tandi Bazar, Narayanghat and local market.

In total 60 percent of goods needed for hotel/lodger are purchased from Tandi and 20 percent from Sauraha, 15 percent from Narayanghat and reaming percent purchase outside of district. It shows that 95percent of demend has been fulfilled from Tandi, Sauraha and Narayanghat. Various local shopkeeper supplies goods to the hotels for tourist purpose.

Table 6 : Market Source Goods

\begin{tabular}{|l|c|c|}
\hline \multicolumn{1}{|c|}{ Market } & Number & $\begin{array}{c}\text { Percentage } \\
\text { of Goods } \\
\text { Purchased }\end{array}$ \\
\hline Tandi & 12 & 60 \\
\hline Sauraha & 4 & 20 \\
\hline Narayanghat & 3 & 15 \\
\hline Outside of District & 1 & 5 \\
\hline Total & 20 & 100 \\
\hline
\end{tabular}

Source: Field Survey, 2009

In total 35 percent demand of green vegetable has been supplying from local shopkeepers. Similarly, 15 percent firewood, 10 percent rice and wheat, 10 percent fish and meat and 35 percent other things (handicraft) has also supplying from local shopkeepers.

Table 7 : Supplying Goods from Local Shopkeeper

\begin{tabular}{|l|c|c|}
\hline \multicolumn{1}{|c|}{ Particular } & $\begin{array}{c}\text { No. of } \\
\text { Respondent }\end{array}$ & Percentage \\
\hline Green vegetable & 7 & 35 \\
\hline Firewood & 3 & 15 \\
\hline Rice and whet & 2 & 10 \\
\hline Fish and Meat & 2 & 10 \\
\hline Other (handicraft) & 6 & 30 \\
\hline Total & 20 & 100 \\
\hline
\end{tabular}

Source Field Survey, 2009

\section{IMPACTS ON SOCIO-ECONOMY}

Before the declaration of Park, Tharus were leading a peaceful environment within the distinct identity. After 1973, most of the non-Tharus started to shift either form hill regions or out-side Sauraha, because of expectation of getting good job in tourism industry. Not only tourists but also local people who travel for different purposes bring in new ideas and behaviors that affect cultural practices. Changes in people behavior, dress, lifestyle, family and social stronger and values and expectations the degradation in local support for local rational and institutions peoples preference for tourist related jobs over education, changed in traditional architecture are generally cited as instances of tourism negative impact on culture. 
There is no doubt that tourism industry in Sauraha has become job oriented industry by which the great number of young men had been secured financially. Employment ranges from the manpower working for the lodges or resorts, to those engaged indirectly in the tourist sector. The majority of local people are employed in the low level management. In the top level management employees of the resorts or hotels are from Kathmandu. The landless people usually sale fire wood, the farmers usually supply vegetables and foods, the farming industries such as fish farming, livestock farming, fruit farming are highly benefited by tourism Industry. Tourism is labor intensive and it absorbs unemployed labor resources which is particularly valuable in as with surplus unskilled labor. In Sauraha more than 1200 people were temporarily employed on daily wages basis. Sauraha has provided employment especially for young people who were completely jobless. Besides employment, indicted economic impact of the local people has been founded in Sauraha. They are increasing the price of land. Similarly, being keeping increase the rental opportunities of land and buildings increase in opportunity of selling local culture to the tourists, increase in opportunities in business. Finally, the tourism in Sauraha has left positive effect in the economy, specially the jobless men and women eagerly taken up a job of guiding touris as well as helping them to transfer their language.

Tourism has also an impact on social conditions of people. The development of tourism has brought a number of changes including conservative social structure. Traditional culture has become wider in sense and the main secular impact is that the man who does not know the English alphabet but can speak English excellent. Tourism infrastructures have been developed. The traditional dress of Tharu has been totally left out. The villagers are closely associated with the tourism because they provide firewood and other necessary things by which they are influenced by the foreigners. The villages have been found some harms associated with tourism development. Specially, children and teenagers might learn bad habits from the tourists. Some residents viewed that the development of tourism may take their villages unsafe. But the harms associated with tourism developement are actually insignificant in comparison to economic benefits.

\section{CONCLUSION}

Tourism sector remains as one of the most important segments of Nepalese economy. An important part of the tourism development in Nepal is that, the number of tourist arrivals and their length of stay has been increased. Chitwan National Park is the third most important destination of the tourists visiting Nepal. Tourism has played a main role in employment generation in Sauraha. Peoples in Sauraha area have been turned and attracted towards tourist trade which has increasingly assisted people to uplift the standard of life and strengthen economically. The local people have been benefited from the development of tourism infrastructure such as transportation, communications and electric facilities. Most of the local people believe that tourism has a good impact on local residents with the growth of tourism. The value of land has been increased. A number of associated activities, especially hotel, fruits farming, vegetable farming, poultry farming and livestock farming are increasing. These activities have been providing employment to local youths. There is a high degree of significant relationship between the hotels facilities and the tourist arrivals. It shows that hotel industry plays a vital role in promoting tourism industry. The number of hotels is increasing every year in this area and it has bright prospects for the well facilitated hotels and lodges. Economic impact of tourism in Sauraha is increasing. Similarly, social impact like life style of people has been changing. Traditional Tharu culture has been becoming wider in the sense that it has been performing the hotels facilities in front of tourists.

\section{REFERENCE}

CBS, 2001, Population of Nepal VDCs/ Municipalities, Population Census 2001 (Central Development Region). Kathmandu: Central Bureau of Statistics, Governemnt of Nepal

CBS, 2001, Chitwan District Profile. Kathmandu: Central Bureau of Statistics, Governemnt of Nepal

Chauhan, Y. S., 2003, Eco Tourism in Nepal, Delhi: Kalinga Publications.

CNP, 2008. Chitwan National Park Booklet, Nepal Tourism Board : Kathmandu: Government of Nepal.

Gupta, S. K., 2002. Tourism and Heritage Resources in Garhwal Himalayan, Delhi: Garhwal Offset Printing.

MoF. 2005/06. Economic Survey. Kathmandu: Ministry of Finance, Government of Nepal.

NTB. 2001 National Ecotourism Strategy and Marketing Programme of Nepal, Kathmandu: Nepal Tourism Board, Government of Nepal.

Satyal, Y. R. 1988. Tourism in Nepal, A profile, Varanasi: Nath Publishing House.

Williams, S. 2004. Tourism: The nature and structure of tourism. Taylor \& Francis 